\title{
Walkability variables: an empirical study in Rolândia - PR, Brazil
}

\author{
Variáveis da caminhabilidade: um estudo empírico em \\ Rolândia - PR, Brasil
}

\section{Ana Luiza Favarão Leão \\ Hugo Queiroz Abonizio \\ Rodrigo Siqueira Reis \\ Milena Kanashiro}

\begin{abstract}
$\mathbf{T}$

he built environment possessed determinants of more active lifestyles, related to social and cultural reality. Thus, relevant walkability variables in large cities and in developed countries may not be suitable for mid-sized Brazilian towns. Therefore, from a

case study, the objective of this research was to evaluate the relevance of eight objective walkability variables: Residential Density; Retail Floor Area Ratio; Mixed Land Use (Entropy); Space Syntax - Integration and Choice; Land and Real Estate values in a case study of a mid-sized Brazilian town. From the geocoding of data from the Municipal Urban Mobility Plan, urban form variables were aggregated and tested in 1000 meter network buffers. Analyzes were performed using a machine learning approach, through the Random Forest algorithm, in relation to self-reported walking (meters walked per unit of area). Results indicated that the most relevant characteristics were: Entropy, Integration within a 2000 meter radius and Residential Density. Contributions include the possibility of subsidizing urban planning policies in adopting an evidence-based approach.
\end{abstract}

Keywords: Built environment. Walkability. Active transport. Urban health.

\section{Resumo}

O ambiente construído possui determinantes de estilos de vida mais ativos, relacionados com a realidade social e cultural. Assim, variáveis da

${ }^{1}$ Ana Luiza Favarão Leão Universidade Estadual de Londrina Londrina - PR - Brasil

${ }^{2}$ Hugo Queiroz Abonizio 2Universidade Estadual de Londrina Londrina - PR - Brasil

${ }^{3}$ Rodrigo Siqueira Reis ${ }^{3}$ Washington University St. Louis - MO - United States

${ }^{4}$ Milena Kanashiro ${ }^{4}$ Universidade Estadual de Londrina Londrina - PR - Brasil

Recebido em 10/04/19 Aceito em 21/12/19 caminhabilidade relevantes em grandes cidades e em países desenvolvidos podem não ser adequados para cidades médias brasileiras. Portanto, o objetivo desta pesquisa foi avaliar a relevância de oito variáveis objetivas da caminhabilidade objetiva: densidade residencial; taxa de ocupação de áreas comerciais; uso misto do solo (entropia); sintaxe espacial - integração e escolha e valores fundiários e imobiliários em um estudo de caso de uma cidade média brasileira. A partir da geocodificação de dados do Plano de Mobilidade Urbana, as variáveis da forma urbana foram agregadas e testadas em buffers de rede de 1000 metros. As análises foram realizadas por meio de uma abordagem de aprendizado de máquina, na utilização do algoritmo Random Forest, em relação à caminhada auto reportada (metros caminhados por unidade de área). Resultados indicaram as características mais relevantes: Entropia, Integração no raio de 2000 metros e Densidade Residencial. Contribuições incluem a possibilidade de subsidiar políticas de planejamento urbano na adoção de uma abordagem baseada em evidências.

Palavras-chave:Ambiente construído. Caminhabilidade. Mobilidade ativa. Saúde urbana. 


\section{Introduction}

According to the World Health Organization, non-communicable diseases such as cardiovascular diseases, hypertension, and type 2 diabetes represent a threat to human development, and the susceptibility to them increases due to physical inactivity (PI) (WORLD..., 2017). Facing the prevalence of PI worldwide and its negative effects on health (DUMITH et al., 2011), understanding aspects that influence active behaviors is paramount. Notwithstanding, active behaviors are shaped by different factors, levels of determinants and their interactions (BAUMAN et al., 2012). Individual variables are widely studied (SALLIS et al., 2016) whereas environmental factors are less researched, despite their recognized effects on behavior (BAUMAN et al., 2012). With the growing burdens of motorized transportation (MURRAY; LOPEZ; CAMBRIDGE, 2014) urban qualities have lead researchers to gain understanding of urban form's influence on travel behavior (CAMPOLI, 2012). They have been centered as important emerging topics in the dialogue concerning sustainability and as the core of city planning strategies of developed countries (GILDERBLOOM; RIGGS; MEARES, 2015). One of the strategies to evaluate the built environment (BE) is walkability, defined as "[...] the extent to which characteristics of the built environment may or may not be conducive to walking for either leisure, exercise or recreation, to access services, or to travel to work [...]" (LESLIE et al., 2007, p. 91). Besides contributing to health, walking is at the core of sustainable mobility, reducing motorized transportation and minimizing environmental impacts. Walking demands fewer resources than other means of transportation, it is cheap, silent, and non-polluting (GEHL, 2013).

In low and middle-income countries, studies on environmental correlates of walking are urgently needed (BAUMAN et al., 2012) to attenuate the rapidly changing determinants of PI that occur due to urbanization, passive entertainment, and motorized transport. Thus, the need for a better understanding of urban mobility patterns in Brazilian cities is evident. Therefore, this research tackles the phenomenon of the BE as support for walking through the study of objective walkability variables in Brazilian cities.

These cities present themselves very differently from high-income countries, in spatial, functional, socioeconomic and environmental qualities (CARMONAet al., 2010). Such differences emphasize the need for context-specific studies in designing and implementing environmental strategies to increase physical activity (PA) levels (SALVO et al., 2014).

Such research interest is made even more relevant in cities where nonmotorized transportation is largely present and public transport is less used (ASSOCIAÇÃO..., 2018). Brazil has most of its cities represented by an average of 5 to 100 thousand inhabitants (INSTITUTO..., 2015). According to the Associação Nacional de Transportes Públicos, active travel by foot is inversely proportional to the dimension of the city - the smaller the city, the higher the rates of active travel (ASSOCIAÇÃO..., 2018). Notwithstanding, there is a lack of studies on walkability in medium and small-sized Brazilian cities (MOTOMURA et al., 2018).

Considering the above-presented topics, the need for a greater understanding of active travel patterns in Brazilian cities is evident for tailored mobility policies. Therefore, the main objective of this research is to evaluate the relevance of objective walkability variables of the BE in a mid-size Brazilian city. To that end, urban form walkability-related characteristics were tested through a comparison with self-reported travel behaviors. This work has the theoretical assumption that when comparing objective walkability variables to travel behaviors on mid-size Brazilian cities it would be possible to uncover the specific variables that influence walking in Brazilian cities.

\section{Background}

The benefits of walking are widely recognized, it is more than a utilitarian mean of transportation. It holds social, recreational and cultural values (SOUTHWORTH, 2005). Walking is the most equitable, accessible and available mean of transportation (ORELLANA; HERMIDA; OSORIO, 2016). The BE is an influence able to facilitate or hinder walking behaviors (SAELENS; HANDY, 2008).

One of the strategies to evaluate BE for supporting a more active daily life are walkability indices, being that the most widespread one was proposed by Frank et al. (2010). It is based on an equation that represents walkability considering four variables: Residential Density, Land use mix (Entropy), Intersection Density, and Retail Floor Area Ratio.

Residential density is considered paramount for shorter and more convenient walking trips. and have positive effects on utilitarian walking, land use balance and street connectivity (SAELENS; SALLIS; FRANK, 2003). The development of higher population densities is one of the factors that can reduce the

476 Leão, A. L. F.; Abonizio, H. Q.; Reis, R. S.; Kanashiro, M. 
number of motorized trips and increase the number of walking trips (CERVERO; KOCKELMAN, 1997). It has been the basis of neighborhoods designed for sustainability with the purpose of housing enough people to be able to support urban services such as local shops, schools and public transport. Even though compacthigh density development is encouraged in contemporary urban planning, it often conflicts with sociocultural contexts (CARMONA et al., 2010), especially in middle-income countries. Seeking optimal densities for development thus remains one of the most challenging of the sustainable urban design principles.

Land-use mix can be seen as a complement to residential density, aiming to quantify the heterogeneity of land uses (DUNCAN et al., 2010). Such attribute has been shown to be associated with walking and other PA behaviors (FRANK et al., 2005). In neighborhoods with a greater mix of uses, utilitarian destinations are within a shorter reach from residences, increasing the convenience for walking (SAELENS; SALLIS; FRANK, 2003). Currently, land use mix is a walkability variable most often assessed through a variation of the Shannon Entropy equations (FRANK; ANDRESEN; SCHMID, 2004; GEBEL; BAUMAN; OWEN, 2009; GRASSER; TITZE; STRONEGGER, 2016) which represents the extent of variation in the distribution of land uses. However, in some studies, land use mix has not been found to be associated with PA behaviors (FORSYTH et al., 2008; GRASSER et al., 2013; MCCORMACK; SHIELL, 2011). Such inconsistent findings may be partly due to the lack of specificity in the land use categories considered (DUNCAN et al., 2010).

A walkability measure naturally connected to land use mix is Retail Floor Area Ratio (FAR), which is the ratio or the sum of commercial building floor area to the total commercially used land area (FRANK et al., 2010). It was created as a reflection of more options for destinations where goods and services may be purchased (LESLIE et al., 2007), but more importantly as a measure of pedestrian-oriented community design. Retail parcels with a high retail floor area ratio may be less likely to have the 'pedestrian-unfriendly' design with large hostile parking lots (CERVERO; KOCKELMAN, 1997). This measure is greatly linked to large retail chains and shopping malls from North American cities. It has even been considered only for large retail activities with three or more shops or a single shop of 250 square meters or larger (LESLIE et al., 2007). It can be interpreted as a derivation of the early metrics of parking ratios, that indicated the relationship between the space allotted for parking and the space occupied by retail buildings (GIBBS, 2012).

Another fundamental walkability measure, street connectivity quantifies the linkage between destinations. It is argued that connectivity is an urban design measure that underpins walkable neighborhoods (KOOHSARI et al., 2016a). Connected street networks provide more direct routes to destinations (FRANK et al., 2010), being a prerequisite for increasing pedestrian activity (ELLIS et al., 2015). Such importance is supported by several empirical findings that indicate consistent positive associations between walking, especially for transport, and street connectivity (BERRIGAN; PICKLE; DILL, 2010; OAKES; FORSYTH; SCHMITZ, 2007; SUGIYAMA et al., 2012). Street connectivity is commonly operationalized as the quantification of intersection density by unit area. It is often represented by the mean block size per area, indicating the average distance between intersection (ELLIS et al., 2015).

Futher,route directness measures based on the configuration of street elements, drawing from the space syntax theories, are also resorted to when representing street connectivity (KOOHSARI et al., 2016b). The space syntax theory, focuses on the spatial relationships between the movement of pedestrians and urban configuration. Described in several seminal works mainly by the theorists Hillier and Hanson (1984), pedestrian movement is thought to be, to a large extent, dependent on the spatial arrangements produced by society. Space syntax analyzes the correspondence between the spatial structure and the social logic of space, seeking to understand the logic that emerges from the urban configuration itself. Hillier et al. (1993) introduces the theory of Natural Movement, presenting evidence that the street network's configuration and connectivity generate central areas with the potential for development of commercial activities and greater pedestrian movement. Hillier states that the configuration of streets is considered the "[...] primary generator of pedestrian movement [...]" (HILLIER et al., 1993, p.32). According to several empirical studies, even in Brazil, space syntax measures are positively correlated with pedestrian movement (ZAMPIERI; RIGATTI, 2008). Researches involving space syntax measures have the potential to contribute with new insights on the relationship between urban form and walking behavior (KOOHSARI et al., 2014). These measurements have shown to be related to several urban spatial characteristics such as the price of land (SCHROEDER; SABOYA, 2015), the location of residential activities (CARVALHO; SABOYA, 2017) and commercial activities (LIMA, 2015). 
Apart from potential environmental, social and individual benefits, walkable neighborhoods have been linked to a naturally occurring increase in property values (GUO; PEETA; SOMENAHALLI, 2017). More walkable areas tend to be more developed and consequently closer to amenities. Such amenities only come to be where their price is sufficiently valued (BOYLE; BARRILLEAUX; SCHELLER, 2014). Hence, walkability has an important connection to urban economies. Therefore, an important aspect to be considered is the ample evidence linking land and real estate values to walkability (GUO; PEETA; SOMENAHALLI, 2017; MATTHEWS; TURNBULL, 2007; RAUTERKUS; MILLER, 2011). Neighborhoods closer to centralities and established in older settlements have been found to be more walkable and more economically valued. Taking such evidence into account, it is safe to conclude that land and property price are environmental/social variables intrinsically related to walkability and walkable characteristics (CHIARADIA et al., 2012).

\section{Data and methodology}

Considering the phenomenon under investigation as real-life and contemporary, dynamic and complex therefore indissociable from its contextuality, the most adequate research strategy is the case study (YIN, 2001), focusing on Rolândia-PR, Brazil. For the development of this strategy, a Correlational methodology was adopted to identify spatial and behavioral patterns with many variables, using statistics (GROAT; WANG, 2002).

On account of database availability and populational representation of a mid-size Brazilian city the selected case study is Rolândia. This city has recently developed its Urban Mobility Plan, therefore an extensive subjective database based on an Origin-Destination (OD) survey was provided by ITEDES- Institute of Technology, Economic, and Social Development. The OD survey collects detailed travel behavior data by asking participants to describe all trips made the day before a questionnaire was applied. The precise addresses of each trip's origin and destination were collected, along with purpose, mode, time of day and duration. A trip was established as any time you went from one address to another in a vehicle, by walking or biking. Each trip made was accounted for, providing data on the pedestrian movement that was spatialized in geoprocessing procedures that connect geocoded origins and destination through georeferenced routes. Walking levels, the final correlational data for this study, is represented by 394 walking trips that were quantified in meters per unit area.

This study has conducted all analysis trough network buffers of 1000 meters extending along the streetnetwork of around the households of respondents. Even though it is suggested that the optimal measurement scale might depend on the research context, this radius follows general literature tendencies that consider BE exposure classifications to 1000 meters, as most walks are shorter than 600m and few exceed $1200 \mathrm{~m}$ (HOUSTON, 2014). Further, the available data regarding self-reported travel behaviors shows a majority of walking trips restricted within the 1000-meter distance range. Therefore, the selected metric reflects walking patterns present in the case study considered.

\section{Table 1 - Objective walkability variables considered}

\begin{tabular}{|l|l|l|}
\hline \multicolumn{2}{|c|}{ Objective Walkability variables } & \multicolumn{1}{c|}{ Measurement methodology } \\
\hline 1 & Residential Density & Residential units per unit of area \\
\hline 2 & Retail Floor-Area Ratio & $\begin{array}{l}\text { Area of the retail parcels divided by the footprint of the retail } \\
\text { building }\end{array}$ \\
\hline 4 & Intersection Density & $\begin{array}{l}\text { The ratio between the number of true intersections (between } \\
\text { three or more roads) and the areal extension of the unit being } \\
\text { considered }\end{array}$ \\
\hline 5 & $\begin{array}{l}\text { Space Syntax Integration (radii range of 100 to } \\
2000 \text { meters with 100-meter intervals) }\end{array}$ & $\begin{array}{l}\text { The measure of diversity of uses present in an area unit, } \\
\text { considering 5 different use categories, calculated through the } \\
\text { following formula based on Shannon (1948) }\end{array}$ \\
\hline 6 & $\begin{array}{l}\text { Space Syntax Choice (radii range of 100 to } \\
2000 \text { meters with 100-meter intervals) }\end{array}$ & $\begin{array}{l}\text { score was calculated for each buffer, for each radius within the } \\
\text { radii range }\end{array}$ \\
\hline 7 & Land Parcel Values & $\begin{array}{l}\text { Mean scores of the values in Reais included in each unit of } \\
\text { analysis. }\end{array}$ \\
\hline 8 & Real Estate Values & indial lines; an average integration and choice \\
\hline
\end{tabular}

The methodological strategy of this research involves evaluating the relevance of objective walkability variables of the BE in the context of a Brazilian city. Tankibg evidence from the literature into account and

478 Leão, A. L. F.; Abonizio, H. Q.; Reis, R. S.; Kanashiro, M. 
the background presented previously in this work, the objective walkability variables considered are presented in Table 1. Data on objective walkability variables were either collected in the field or provided by the city hall of the case study. All data were geocoded by the researchers using the ArcGis 10.6.

Residential density is a measure of the number of residential units per unit of area (SAELENS; SALLIS; FRANK, 2003). After counting all the households in the municipality of Rolândia, the residential density ratio was calculated for each unit of analysis considered.

Retail floor area ratio measures the area of the retail parcels divided by the footprint of the building destined for retail use. A low ratio would indicate that the plot is likely to direct more parking area while a larger value would indicate less surface area to be intended for this purpose. Dedicating less urban surface to parking lots is understood as facilitating pedestrian access (FRANK et al., 2010).

Intersection density is a measure related to the connectivity of the street network, represented by the ratio between the number of true intersections (between three or more roads) and the areal extension of the unit being considered (FRANK et al., 2010). This measure is, therefore obtained by the division of $\mathrm{N}$ true intersections contained in a unit and the area in square meters of that same unit.

Entropy, or land use mix, is a measure of the diversity of uses present in an area unit. In this research, taking as a starting point the work proposed by Frank et al. (2010), the mixture between 5 uses was considered: residential, commercial, entertainment services (including restaurants, for example), and institutional (including schools, government buildings, etc.). The resulting values are normalized between 0 and 1 , where 0 would indicate the existence of only one use in a given area and 1 would indicate a complete and equal distribution of the five uses. The entropy was calculated through the equation proposed by Shannon (1948).

Space Syntax seeks to describe, through quantitative measures, the configuration of the urban grid, relationships between public and private space, the urban system as the distribution of land use, cohesion and social exclusion, accessibility and security (CARVALHO; SABOYA, 2017). In space syntax, the urban space is divided into spatial units known as axial lines. These are the longest straight lines capable of covering a whole system of public spaces (HILLIER; HANSON, 1984)The relations between axial lines of a system can be analyzed through the Integration (1) and Choice (2) measures. Both were calculated trough axial lines generated from street centerline data provided by the city hall of Rolândia. Then, axial lines were imported into the QGIS software, a free and open-source GIS. Through the Space Syntax toolkit, the syntactic integration and choice measures were calculated for each street segment in radii ranging from 100 to 2000 with 100 meter intervals.

Land price and real estate property price were obtained in the city hall of the case study under analysis. In this study, such data was considered as walkability constructs. Land prices and real estate prices are represented as mean scores of the values in Reaisincluded in each unit of analysis.

The relationship between objective walkability variables and walking was analyzed through a Machine Learning approach. The Random Forest (RF) ensemble learning method for regression, proposed by Breiman (2001), was applied. RF has excellent performance and, although it is not widely used in the urban planning field of study, it has several characteristics that make it ideal for its datasets. Some advantages of $\mathrm{RF}$ are the good predictive performance even when most predictive variables are noisy; does not require preselection of features; not prone to overfitting; handles both categorical and continuous predictors; incorporates interactions among predictor variables; and returns measures of variable importance (DÍAZURIARTE; ALVAREZ DE ANDRÉS, 2006). Given these promising qualities, all individual variables considered in this research were tested using RF.

The RF quality measure of a model is the output value of the coefficient of determination $\left(\mathrm{R}^{2}\right) . \mathrm{R}^{2}$ is defined as "the proportion of variance explained by the regression model" (NAGELKERKE, 1991). Thus, it can be seen as a measure of the model's success in predicting the dependent variable through the independent ones.

The most relevant output from RF is an importance measure of the predictor variables. Variable importance is a difficult concept to define in general, because the relevance of a variable may be due to its possibly complex interaction with other variables (LIAW; WIENER, 2002). In summary, the random forest algorithm estimates the importance of a variable by looking at how much prediction error increases when data for that variable is permuted while all others are left unchanged. In this work, feature importance was extracted with the intention of analyzing variables that are more related to the response variable, walking levels.

RF is a truly 'random' method, its results can vary from run to run. The verification of model stability is of utmost importance $(\mathrm{SHIH}, 2011)$. Therefore, $\mathrm{R}^{2}$ was cross-validated to obtain its distribution. Crossvalidation is an essential common practice to avoid overfitting, the production of an analysis that 
corresponds too closely or exactly to a particular set of data, and may, therefore, fail to fit additional data or predict future observations reliably (EVERITT; SKRONDAL, 2010). In summary, it verified how well the model will generalize to new data. A random permutations cross-validation (or Shuffle \& Split) was conducted for the results reported.

The RF Regression was implemented using the Scikit-learn machine learning library for the Python programming language (PEDREGOSA et al., 2012). This language was chosen due to its ample use in geoprocessing (DOBESOVA, 2011; GRASER; OLAYA, 2015).

\section{Results}

A RF regression model was constructed. The dependent variable was walking levels (meters walked per unit area) and predictor variables were those present in Table 01. After cross-validation through the Shuffle \& Split method, the final $\mathrm{R}^{2}$ value was obtained. A mean $\mathrm{R}^{2}$ of 0.859 (Table 2) indicates a satisfactory model performance. The best possible score is 1.0 and it can be negative (because the model can be arbitrarily worse) (PEDREGOSA et al., 2012). The standard deviation for the model seems to be minimal (SD = 0,086).

The measure of importance indicates the variables that are more closely related to the dependent one and contribute more for its variation. The 10 most relevant variables can be observed in Table 3 . The most relevant individual variables were Entropy, Integration at a $2000 \mathrm{~m}$ radius $(0.236)$ and Residential density (0.060), however, the land use mix variable presented itself as substantially better than the others, with an importance value over 4 times larger than the second most important feature.

A bar graph was generated to visually verify the distribution of feature importance values. As can be observed in Figure 1, there is an importance disproportion: Entropy is found at an excelling position of advantage over other variables.

Results indicate that Entropy (Figure 2) seems to be strongly associated with walking, consistent with previous studies on land use patterns. Land use mix is at the base of many urban planning and transport studies, in that people move between activities located in different places. If activities are close enough to make walking easier, more people will probably walk (FORSYTH et al., 2008). Mixed-use is also thought to provide more visual variety and informal policing. To date, many studies have found a number of destinations to be associated with active travel, especially walking (GILES-CORTI et al., 2005; LEE; MOUDON, 2006a). Considering such outcome, we are led to believe that measuring entropy using the Shannon equation can minimize possible bias. One aspect to highlight in this study is that, despite literature evidence (GUO; PEETA; SOMENAHALLI, 2017; MATTHEWS; TURNBULL, 2007), no relationship was found between property or land values with walkability.

Table 2 - Mean $\mathbf{R}^{2}$ and standard deviation of $\mathbf{R F}$ regression

RF regression model at a $1000 \mathrm{~m}$ street network buffer aggregation scale

\begin{tabular}{l|l}
\hline Mean $\mathrm{R}^{2}$ & 0.859 \\
Standard Deviation & 0.086 \\
\hline
\end{tabular}

Source: developed by the authors.

Table 3- Variable importance for RF regression model

\begin{tabular}{c|l}
\hline Importance & \multicolumn{1}{|c}{ Variable } \\
\hline 0.609 & Entropy \\
0.236 & Integration r2000 \\
0.060 & Residential Density \\
0.033 & Integration Rn \\
0.014 & Integration r1900 \\
0.013 & Mean Parcel Price \\
0.010 & Mean Estate Price \\
0.010 & Intersection Density \\
0.009 & Choice r1500 \\
0.009 & Integration r100 \\
\hline
\end{tabular}

Source: developed by the authors.

480 Leão, A. L. F.; Abonizio, H. Q.; Reis, R. S.; Kanashiro, M. 
Figure 1 - Feature importance histogram of RF regression

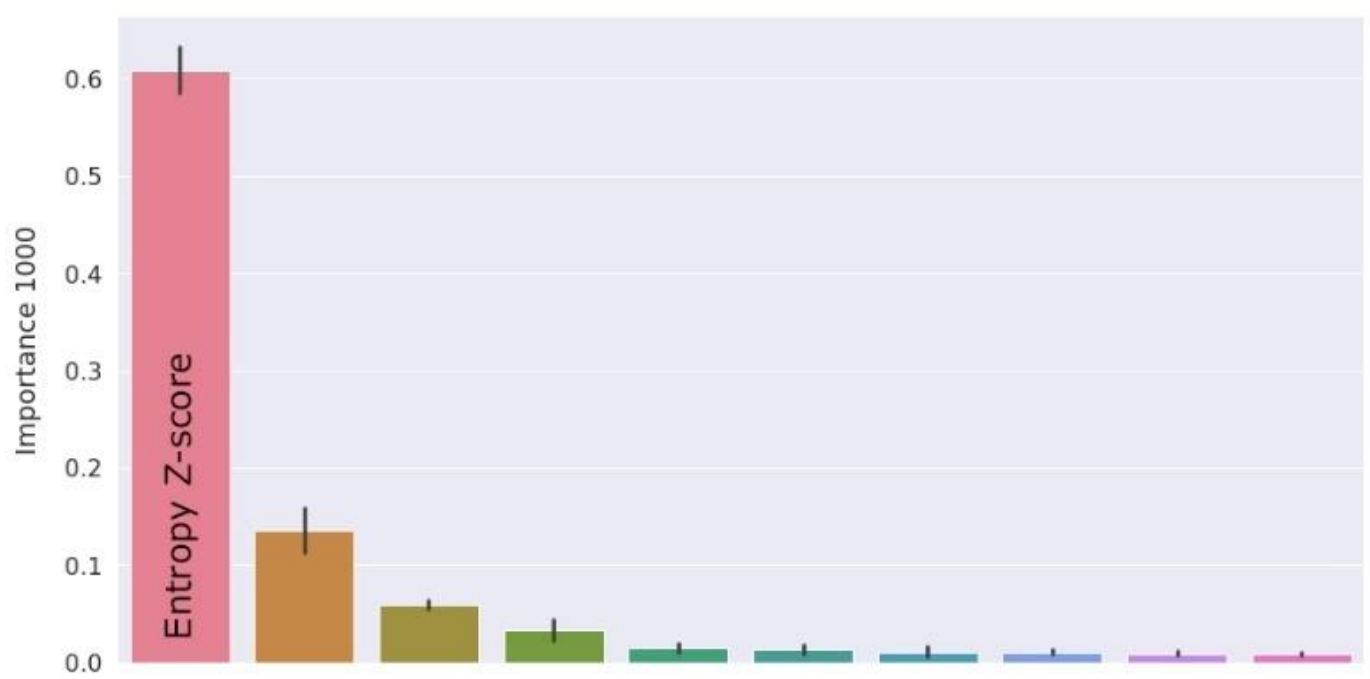

Source: developed by the authors.

Figure 2 - Entropy Z-score map at the 1000 m street network scale

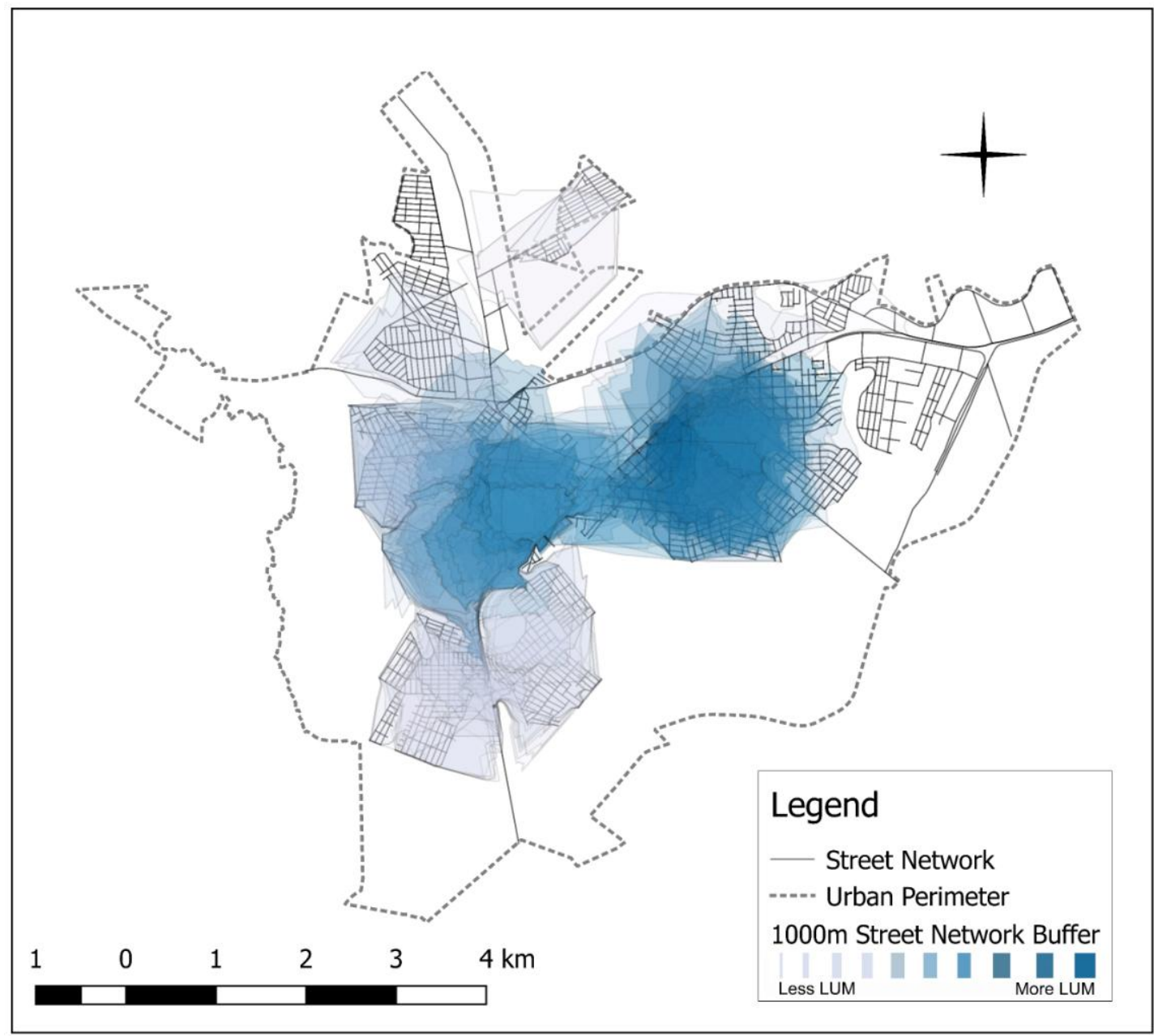

Source: developed by the authors. 
The second RF finding indicated the relevance of the Integration Z-score at a $2000 \mathrm{~m}$ radius variable (Figure 3 ), supporting Hillier's theory and indicating that syntactic measures produce better outcomes when analyzing pedestrian movement than more common connectivity measures in walkability studies, such as intersection density (KOOHSARI et al., 2016a). Hillier and colleagues have argued that street network, which is essentially a formal aspect of urban form, could influence pedestrian movement through the different distribution of commercial land uses according to the level of integration (HILLIER; HANSON, 1984). Considering the scale of the study case under investigation, the broader ranges of integration, that reach as much of the system as possible, were better related to walking. Therefore, the calculations that included the global Integration measure and the larger $2000 \mathrm{~m}$ local radius, which reaches whole sections of the system, had more relevant results.

Many studies have been carried out over the past two decades on the correlations that can be found between pedestrian flow and syntactic measures of local integration. The basic conclusion is that local integration can be used to study people's movements within urban systems (JIANG; CLARAMUNT; KLARQVIST, 2000). Such conclusions are of great impact as a tool for urban planners and designers to foresee pedestrian movement by analyzing morphological structures using space syntax techniques.

Residential density Z-score (Figure 4) also showed to be significant. This result is supported by the literature, such as in the study conducted by Frank and colleagues (FRANK et al., 2008), where individuals were more likely to walk if they lived in neighborhoods with greater residential density. Alike in the study conducted by Lee and Moudon (2006b), residential density measures were found to be significantly associated with walking both at the parcel level and at the $1 \mathrm{~km}$ buffer area level. Overall, higher densities have many benefits in terms of efficient use of infrastructure, housing affordability and street life (FORSYTH et al., 2007).

Figure 3 - Integration r2000m Z-score map at the $1000 \mathrm{~m}$ street network scale

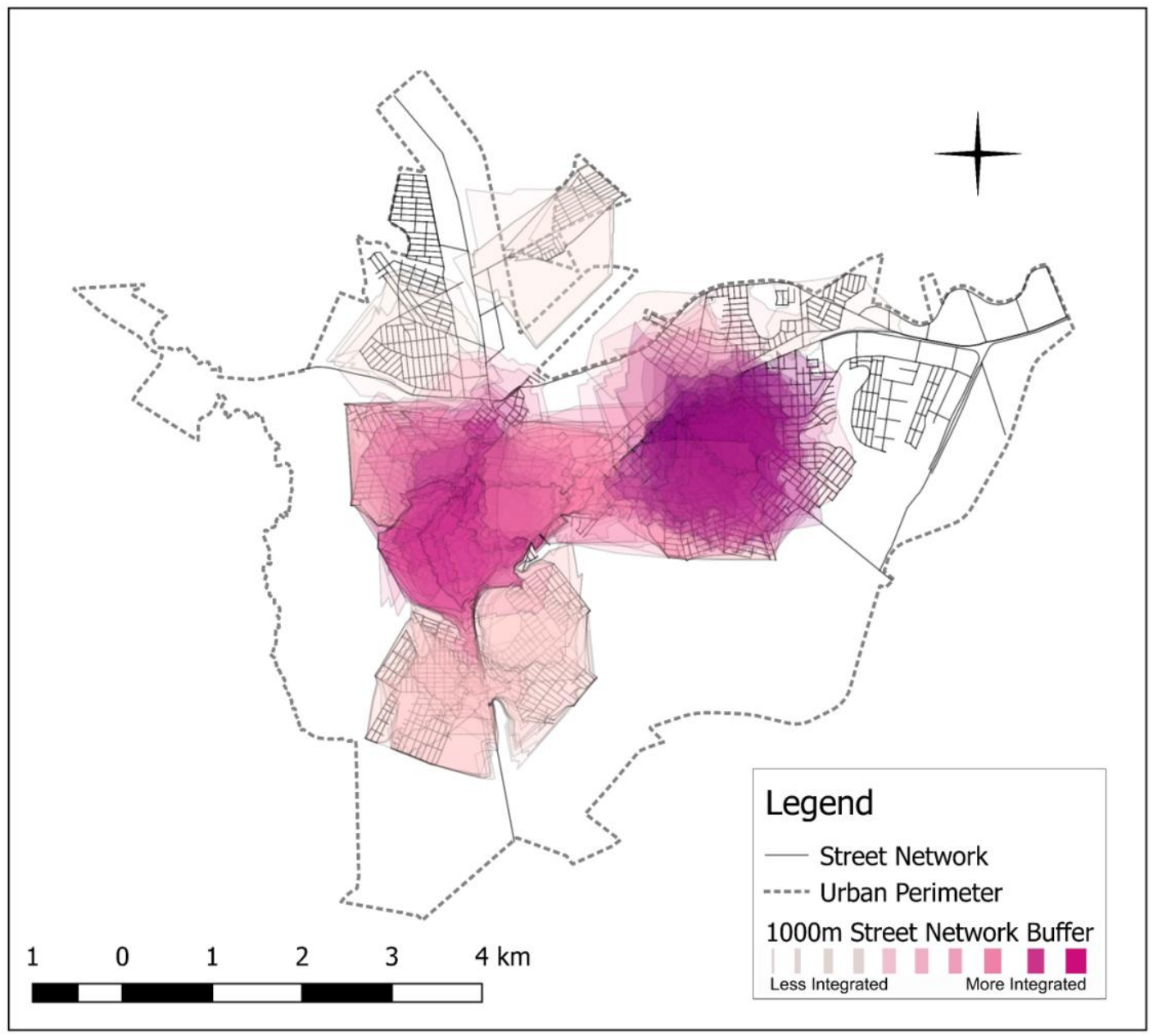

Source: developed by the authors.

482 Leão, A. L. F.; Abonizio, H. Q.; Reis, R. S.; Kanashiro, M. 
Figure 4 - Residential density Z-score map at the $1000 \mathrm{~m}$ street network scale

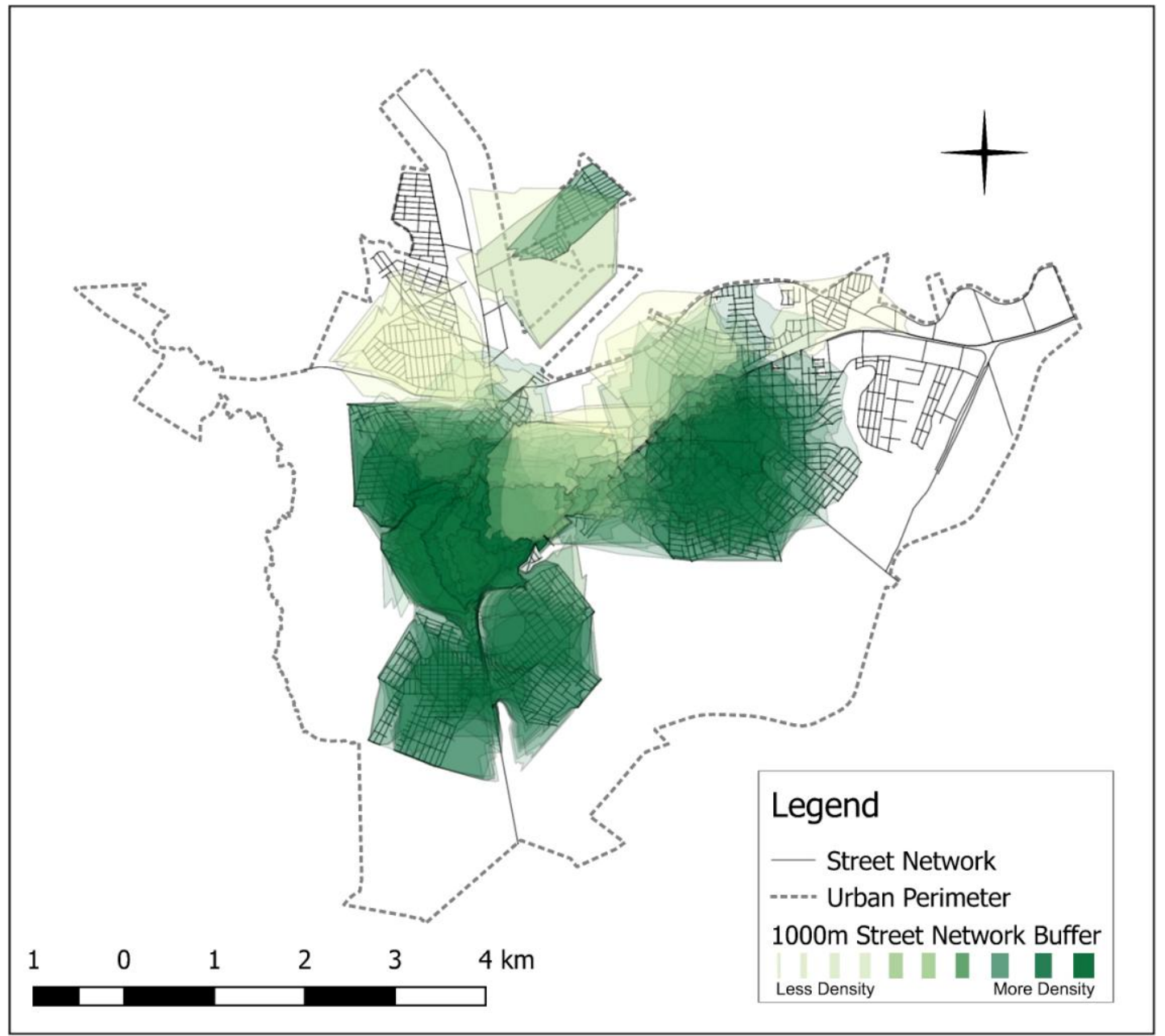

Source: developed by the authors.

\section{Discussions}

This researches' aim was to evaluate the relevance of individual objective walkability measures in a midsize Brazilian city. To that end, urban form variables were tested for a deeper understanding of the phenomenon. The analysis and results indicated that the BE as a support for walking on a mid-size Brazilian city is a particularly contextual phenomenon.

When comparing individual objective walkability variables to self-reported walking on the mid-size Brazilian city of Rolândia, it was possible to uncover the specific spatial elements that influence walking. The urban form measures of Entropy, Space Syntax integration at the $2000 \mathrm{~m}$ radius, and Residential Density were identified as being more strongly related to walking. Entropy,specifically, was found to be the main correlate of walking. These findings are consistent with the literature as they represent, in a contextspecific way, the traditional 3D's concept of land-use Diversity, pedestrian-oriented Design, and Density(CERVERO; KOCKELMAN, 1997).

Land-use diversity (land-use mix) is represented here by the Entropy measure, which has consistently been found associated with walking (SAELENS; HANDY, 2008). Density is represented by the Residential density variable, regarded as important as it directly affects the compactness of an area, influencing walking (MOUDON et al., 2006). Design usually encompasses street connectivity - describing the degree to which destinations are connected by streets (LU; XIAO; YE, 2017). The most common method for assessing connectivity in walkability studies is intersection density (FRANK et al., 2005; OWEN et al., 2007), however, this work's results indicate that the space syntax measure of local integration greatly surpassed the traditional metric for street connectivity in its relevance to predict walking levels. When compared with 
intersection density, the space syntax measure of integration is less intuitive and thus may be more difficult to grasp for practitioners and decision-makers. Nonetheless, space syntax has in its favorgreater ease of obtaining necessary data, the properties of capturing aspects of the street network that are relevant to pedestrians and the possibility of identifying connectivity not only of an area but also of a single street segment (KOOHSARI et al., 2016a).

After such considerations, one important aspect of the performance of individual walkable urban form variables is the superior relevance of Entropy. This means that land use mix may exert the main role in impacting walking levels in the context of a mid-size Brazilian city. Recent evidence presented by Humberto et al. (2019) for the city of São Paulo exemplifies the context of a larger Brazilian city, where an index containing the variable Diversity of land uses was tested on its relationship to pedestrian movement and yielded insufficient results. Therefore, as hypothesized, the environmental variables related to walking behavior are not necessarily the same in mid-size Brazilian cities as in larger ones or high income developed countries. Consequently, there is a demand for specific approaches to measuring the objective walkabilitybuilt environment effectively, possibly considering land use mix as a central walkability measure.

\section{Conclusions}

This study provided an exploration of the relevance of several walkability constructs in a mid-size Brazilian city. This analysis was conducted through the understanding of these measures in relation to walking levels. When analyzing walkability measures of the BE in relation to walking levels, the most relevant variables were entropy, the space syntax measure of integration at a $2000 \mathrm{~m}$ radius and residential density. These findings are of great implication to the operationalization of walkabilitymeasurement in Brazilian cities, indicating that more widespread walkability variables, such as intersection density, might not be suited for our social, cultural and urban reality. Further, this outcome indicates the relevance of mesoscale walkability measures in predicting walking behaviors and representing walkability.

The literature emphasizes the need for policy-relevant interdisciplinary research, which may lead to more contextually desirable outcomes (SALLIS et al., 2016). This work goes towards this recommendation, presenting methods that include a case study, with an emphasis on local evidence, that may lead interventions in specific urban environments. Considering the relevance of land use mix, residential density and space syntax to walking behaviors, guidance for designing urban developments to support walkable communities could be subsidized.

This study presents some limitations but also moves forward in the discussion of specific walkability variables for mid-size Brazilian cities. The main limitation is that the OD survey has not been created in the specificity of analyzing walkability, even though the database was an important and coherent source of information.

It is essential to emphasize that the authors acknowledge the limitation in the self-report information approach (RIBEIRO et al., 2014), recall bias and inaccuracy are always a possibility.

It must be highlighted that entropy was measured in this study in a detailed-systematic approach, considering specific land use categories for walkability analysis and building typologies, though data constructed by the authors' research group. Such specificity has, probably, contributed to the outcome of this research. However, such data is not readily available in most municipalities of Brazil, making it difficult to so precisely utilize the entropy variable effectively or create comparisons between case studies.

Furthermore, as the relationship between people and their environment changes over time, using longitudinal study designs is of utter importance (RIVA; GAUVIN; BARNETT, 2007). To investigate how walking behaviors are influenced by the BE it is necessary to outperform cross-sectional associations through prospective and intervention studies that uncover the relationships between environment and behavior, indicating causality (OWEN et al., 2004).

And finally, it must be emphasized that the relevant variables discussed here have a threshold of positive influence on walking. We do not indicate such a quantity baseline. It can only be inferred that such variables influence walking behaviors.

In the research paradigm that aims to analyze the existing relationships between urban form and active travel, it is understood that BE characteristics can influence travel patterns. In this study, indications of how walkability variables might affect walking behaviors in Brazil are made, pointing out the outstanding influence of Land Use Mix over walking levels. Considering such an outcome, it is necessary to further

484 Leão, A. L. F.; Abonizio, H. Q.; Reis, R. S.; Kanashiro, M. 
investigate how walkability indices, composite metrics of individual walkability variables, might be effective for the Brazilian urban scenario. The walkability approach to understanding urban form can provide insights on how the BE might contribute to active human behaviors that can possibly subsidize strategies to promote daily life PA in the mid-size Brazilian city scenario.

\section{References}

ASSOCIAÇÃO NACIONAL DE TRANSPORTES PÚBLICOS. Sistema de informações da mobilidade urbana: relatório geral 2016. 2018. Disponível em: http://files.antp.org.br/simob/simob-2016-v6.pdf. Acesso em: 3 maio. 2019.

BAUMAN, A. E. et al. Correlates of physical activity: why are some people physically active and others not? The Lancet, v. 380, n. 9838, p. 258-271, 2012.

BERRIGAN, D.; PICKLE, L. W.; DILL, J. Associations between street connectivity and active transportation. International Journal of Health Geographics, v. 9, n. 1, p. 20, 2010.

BOYLE, A.; BARRILLEAUX, C.; SCHELLER, D. Does walkability influence housing prices? Social Science Quarterly, v. 95, n. 3, p. 852-867, 2014.

BREIMAN, L. Random forests. Machine Learning Journal, v. 45, n. 1, p. 5-32, 2001.

CAMPOLI, J. Made for walking: density and neighborhood form. 2. ed. Cambridge: Lincoln Institute of Land Policy, 2012.

CARMONA, M. et al. Public urban spaces: the dimensions of urban design. Oxford: Architectural Press, 2010.

CARVALHO, A.; SABOYA, R. T. de. A localização residencial em uma cidade vertical : um estudo sintático em Florianópolis. Revista Brasileira de Gestão Urbana, v. 9, n. 3, p. 414-429, 2017.

CERVERO, R.; KOCKELMAN, K. Travel demand and the 3Ds: density, diversity, and design. Transportation Research Part D: Transport and Environment, v. 2, n. 3, p. 199-219, 1997.

CHIARADIA, A. et al. Compositional and urban form effects on centres in Greater London. Proceedings of the Institution of Civil Engineers - Urban Design and Planning, v. 165, n. 1, p. 21-42, 2012.

DÍAZ-URIARTE, R.; ALVAREZ DE ANDRÉS, S. Gene selection and classification of microarray data using random forest. BMC Bioinformatics, v. 7, p. 1-13, 2006.

DOBESOVA, Z. Programming language Python for data processing. In: INTERNATIONAL CONFERENCE ON ELECTRICAL AND CONTROL ENGINEERING, Yichang, 2011. Proceedings [...] Yichang, 2011.

DUMITH, S. C. et al. Worldwide prevalence of physical inactivity and its association with human development index in 76 countries. Preventive Medicine, v. 53, n. 1/2, p. 24-28, 2011.

DUNCAN, M. J. et al. Relationships of land use mix with walking for transport: do land uses and geographical scale matter? Journal of Urban Health, v. 87, n. 5, p. 782-795, 2010.

ELLIS, G. et al. Connectivity and physical activity : using footpath networks to measure the walkability of built environments. Environment and Planning B: Planning and Design, v. 42, n. 1, p. 1-22, 2015.

EVERITT, B. S.; SKRONDAL, A. The Cambridge dictionaryof statistics. $4^{\text {th }}$. ed. Cambridge: Cambridge University Press, 2010.

FORSYTH, A. et al. Design and destinations: factors influencing walking and total physical activity. Urban Studies, v. 45, n. 9, p. 1973-1996, 2008.

FORSYTH, A. et al. Does residential density increase walking and other physical activity? Urban Studies, v. 44, n. 4, p. 679-697, 2007.

FRANK, L. D. et al. A hierarchy of sociodemographic and environmental correlates of walking and obesity. Preventive Medicine, v. 47, n. 2, p. 172-178, 2008.

FRANK, L. D. et al. Linking objectively measured physical activity with objectively measured urban form: Findings from SMARTRAQ. American Journal of Preventive Medicine, v. 28, n. 2, p. 117-125, supp. 2, 2005. 
FRANK, L. D. et al. The development of a walkability index: application to the Neighborhood Quality of Life Study. British Journal of Sports Medicine, v. 44, n. 13, p. 924-933, 2010.

FRANK, L. D.; ANDRESEN, M. A.; SCHMID, T. L. Obesity relationships with community design, physical activity, and time spent in cars. American Journal of Preventive Medicine, v. 27, n. 2, p. 87-96, 2004.

GEBEL, K.; BAUMAN, A.; OWEN, N. Correlates of Non-Concordance between Perceived and objective measures of walkability. Annals of Behavioral Medicine, v. 37, n. 2, p. 228-238, 2009.

GEHL, J. Cidade para pessoas. 2. ed. São Paulo: Editora Perspectiva, 2013.

GIBBS, R. Principles of urban retail planning \& development. New Jersey: Jon Wiley and Sons, 2012.

GILDERBLOOM, J. I.; RIGGS, W. W.; MEARES, W. L. Does walkability matter? An examination of walkability's impact on housing values, foreclosures and crime. Cities, v. 42, n. PA, p. 13-24, 2015.

GILES-CORTI, B. et al. Understanding physical activity environmental correlates: Increased specificity for ecological models. Exercise and Sport Sciences Reviews, v. 33, n. 4, p. 175-181, 2005.

GRASER, A.; OLAYA, V. Processing: a Python Framework for the seamless integration of geoprocessing tools in QGIS. ISPRSInternational Journal of Geo-Information, v. 4, n. 4, p. 2219-2245, 2015.

GRASSER, G. et al. Objectively measured walkability and active transport and weight-related outcomes in adults: a systematic review. International Journal of Public Health, v. 58, n. 4, p. 615-625, 2013.

GRASSER, G.; TITZE, S.; STRONEGGER, W. J. Are residents of high-walkable areas satisfied with their neighbourhood? Journal of Public Health, v. 24, n. 6, p. 469, 2016.

GROAT, L.; WANG, D. Architectural research methods. $2^{\text {nd. }}$ ed. Danvers: John Wiley \& Sons, Incorporated, 2002.

GUO, Y.; PEETA, S.; SOMENAHALLI, S. The Impact of walkable environment on single family residential property values. Journal of Transport and Land Use, v. 10, n. 1, p. 241-261, 2017.

HILLIER, B. et al. Natural movement: or, configuration and attraction in urban pedestrian movement. Environment and Planning B: Planning and Design, v. 20, n. 1, p. 29-66, 1993.

HILLIER, B.; HANSON, J. The social logic of space. Cambridge: Cambridge university press, 1984.

HOUSTON, D. Implications of the modifiable areal unit problem for assessing built environment correlates of moderate and vigorous physical activity. Applied Geography, v. 50, p. 40-47, 2014.

HUMBERTO, M. et al. Walking and walkability: do built environment measures correspond with pedestrian activity? Ambiente Construído, Porto Alegre, v. 19, n. 4, p. 23-36, out./dez. 2019.

INSTITUTO BRASILEIRO DE GEOGRAFIA E ESTATÍSTICA. Estimativas populacionais dos municípios em 2015. 2015. Disponível em:

http://saladeimprensa.ibge.gov.br/noticias?view=noticia\&id=1\&busca=1\&idnoticia=2972. Acesso em: 25 jul. 2017.

JIANG, B.; CLARAMUNT, C.; KLARQVIST, B. Integration of space syntax into GIS for modelling urban spaces. ITC Journal, v. 2, n. 3-4, p. 161-171, 2000.

KOOHSARI, M. J. et al. Mismatch between perceived and objectively measured land use mix and street connectivity : associations with neighborhood walking. Journal of Urban Health, v. 92, n. 2, p. 242-252, 2014.

KOOHSARI, M. J. et al. Street network measures and adults' walking for transport: application of space syntax. Health and Place, v. 38, p. 89-95, 2016 b.

KOOHSARI, M. J. et al. Walkability and walking for transport: characterizing the built environment using space syntax. International Journal of Behavioral Nutrition and Physical Activity, v. 13, n. 1, 2016 a.

LEE, C.; MOUDON, A. V. Correlates of walking for transportation or recreation purposes. Journal of Physical Activity \& Health, v. 3, p. 77-98, 2006a.

LEE, C.; MOUDON, A. V. The 3Ds + R: quantifying land use and urban form correlates of walking. Transportation Research Part D, v. 11, p. 204-215, 2006b. 
LESLIE, E. et al. Objectively assessing 'walkability' of local communities: using GIS to identify the relevant environmental attributes. Berlin, Heidelberg: Springer, 2007.

LIAW, A; WIENER, M. Classification and regression by randomForest. R news, v. 2, p. 18-22, dec. 2002.

LIMA, L. D. S. E. Centralidades em redes espaciais urbanas e localização de atividades econômicas. Porto Alegre, 2015. Dissertação (Mestrado em Engenharia Civil) - Programa de Pós-Graduação em Planejamento Urbano e Regional, Universidade Federal do Rio Grande do Sul, Porto Alegre, 2015.

LU, Y.; XIAO, Y.; YE, Y. Urban density, diversity and design: Is more always better for walking? A study from Hong Kong. Preventive Medicine, v. 103, p. S99-S103, 2017.

MATTHEWS, J. W.; TURNBULL, G. K. Neighborhood street layout and property value: the interaction of accessibility and land use mix. Journal of Real Estate Finance and Economics, v. 35, n. 2, p. 111-141, 2007.

MCCORMACK, G. R.; SHIELL, A. In search of causality: a systematic review of the relationship between the built environment and physical activity among adults. The International Journal of Behavioral Nutrition and Physical Activity, v. 8, p. 125, 2011.

MOTOMURA, M. C. et al. Understanding walkable areas: applicability and analysis of a walkability index in a Brazilian city. Ambiente Construído, Porto Alegre, v. 18, n. 4, p. 413-425, out./dez. 2018.

MOUDON, A. V. et al. Operational definitions of waikable neighborhood: theoretical and empirical insights. Journal of Physical Activity and Health, v. 3, p. s99-s117, supp. 1, 2006.

MURRAY, C.; LOPEZ, A. D.; CAMBRIDGE, M. A. Transport for health: the global burden of disease from motorized road transport. The world bank; Institute for heath metrics and Evaluation. Seattle, 2014.

NAGELKERKE, N. J. D. A note on a general definition of the coefficient of determination. Biometrika, v. 78, n. 3, p. 691-692, 1991 .

OAKES, J. M.; FORSYTH, A.; SCHMITZ, K. H. The effects of neighborhood density and street connectivity on walking behavior: the twin cities walking study. Epidemiologic Perspectives \& Innovations, v. 4, n. 16, 2007.

ORELLANA, D.; HERMIDA, C.; OSORIO, P. A multidisciplinary analytical framework for studying active mobility patterns. In: GONGRESS OF INTERNATIONAL ARCHIVES OF THE PHOTOGRAMMETRY, REMOTE SENSING AND SPATIAL INFORMATION SCIENCES, 23., Prague, 2016. Proceddings [...] Prague, 2016.

OWEN, N. et al. Neighborhood walkability and the walking behavior of Australian adults. American Journal of Preventive Medicine, v. 33, n. 5, p. 387-395, 2007.

OWEN, N.et al. Understanding environmental influences on walking: Review and research agenda. American Journal of Preventive Medicine, v. 27, n. 1, p. 67-76, 2004.

PEDREGOSA, F. et al. Scikit-learn: machine learning in Python. Journal of Machine Learning Research, v. 12, p. 2825-2830, 2012.

RAUTERKUS, S. Y.; MILLER, N. G. Residential land values and walkability. Journal of Sustainable Real Estate, v. 3, n. 1, p. 23-43, 2011.

RIBEIRO, M. D. et al. Influence of GPS and self-reported data in travel demand models. Procedia - Social and Behavioral Sciences,v. 162, p. 467-476, Panam,2014.

RIVA, M.; GAUVIN, L.; BARNETT, T. A. Toward the next generation of research into small area effects on health: a synthesis of multilevel investigations published since July 1998. Journal of Epidemiology and Community Health, v. 61, n. 10, p. 853-861, 2007.

SAELENS, B. E.; HANDY, S. L. Built environment correlates of walking: a review. Medicine and Science in Sports and Exercise, v. 40, n. 7, p. 550-566, supp. 1, 2008.

SAELENS, B. E.; SALLIS, J. F.; FRANK, L. D. Environmental correlates of walking and cycling: findings from the transportation, urban design, and planning literatures. Annals of Behavioral Medicine, v. 25, n. 2, p. 80-91, 2003.

SALLIS, J. F. et al. Use of science to guide city planning policy and practice: how to achieve healthy and sustainable future cities. The Lancet, v. 388, n. 10062, p. 2936-2947, 2016. 
SALVO, D. et al. Characteristics of the built environment in relation to objectively measured physical activity among Mexican adults, 2011. Preventing Chronic Disease, v. 11, 2014.

SCHROEDER, T.; SABOYA, R. T. De. Configurational characteristics of sociospatial segregation in Brazilian cities.In: INTERNATIONAL SPACE SYNTAX SYMPOSIUM, 10., London, 2015. Proceedings [...]London, 2015.

SHANNON, C. E. A Mathematical theory of communication. Bell System Technical Journal, v. 27, n. 3, p. 379-423, 1948.

SHIH, S. Random forests for classification trees and categorical dependent variables: an informal Quick Start R Guide- Report, Stanford University, 2011.

SOUTHWORTH, M. Designing the walkable city. Journal of Urban Planning and Development, v. 131, n. 4, p. 246-257, 2005.

SUGIYAMA, T. et al. Destination and route attributes associated with adults' walking: a review.

MedicineAnd Science In Sports And Exercise, v. 44, n. 7, p. 1275-1286, 2012.

WORLD HEALTH ORGANIZATION. Noncommunicable diseases progress monitor 2017. 2017.

YIN, R. K. Estudo de caso: planejamento e métodos. 2. ed. São Paulo: Bookman, 2001.

ZAMPIERI, F. L.; RIGATTI,D. A atividade comercial como potencializadora do movimento de pedestres nos centros urbanos: um modelo baseado em redes neurais artificiais. In: COLÓQUIO [INTER]NACIONAL SOBRE COMÉRCIO E CIDADE, 2., São Paulo, 2008. Anais [...] São Paulo, 2008.

\title{
Acknowledgments
}

We thank the National Council for the Improvement of Higher Education (CAPES) for the scholarship, the components the Urban Environmental Design Research Group for their support, and the evaluators for their contributions.

Ana Luiza Favarão Leão

Departamento de Arquitetura e Urbanismo | Universidade Estadual de Londrina | Rodovia Celso Garcia Cid - PR 445 Km 380 , Campus Universitário | Caixa Postal 10.011 | Londrina - PR - Brasil | CEP 86057-970 | Tel.: (43)99128-7879 | E-mail: analuiza.favarao@uel.br

Hugo Queiroz Abonizio

Departamento de Computação | Universidade Estadual de Londrina | Tel.: (43)99680-0262 | E-mail: hugo.abonizio@uel.br

Rodrigo Siqueira Reis

Brown School Master of Public Health | Washington University | Hillman Hall 224 | Campus Box 1196 | One Brookings Drive | St. Louis MO - United States | 63130 | Tel.: +(314) 935-4948 | E-mail: reis.rodrigo@wustl.edu

Milena Kanashiro

Departamento de Arquitetura e Urbanismo | Universidade Estadual de Londrina | Tel.: (43)99151-1997 | E-mail: milena@uel.br

\author{
Ambiente Construído \\ Revista da Associação Nacional de Tecnologia do Ambiente Construído \\ Av. Osvaldo Aranha, $99-3^{\circ}$ andar, Centro \\ Porto Alegre - RS - Brasil \\ CEP 90035-190 \\ Telefone: +55 (51) 3308-4084 \\ Fax: +55 (51) 3308-4054 \\ www.seer.ufrgs.br/ambienteconstruido \\ E-mail: ambienteconstruido@ufrgs.br
}

cC) This is an open-access article distributed under the terms of the Creative Commons Attribution License. 